\title{
The discovery and mapping to chromosome 21 of the Alzheimer's amyloid gene: History revised
}

\author{
Nikolaos K. Robakis \\ Department of Neurobiology and Psychiatry, Mount Sinai School of Medicine, NYU, One Gustave Levy Pl. Box \\ 1229, New York, NY 10029, USA \\ Tel.: +1 212241 9380; Fax: +1 212831 1947; E-mail: nikos.robakis@mssm.edu
}

I was invited by the editor of the Journal of Alzheimer's Disease to give a short account of our efforts twenty years ago to clone the gene that encodes the amyloid- $\beta$ peptide, or beta $(\beta)$-protein as it was called. At that time, I was at the New York State Institute for Basic Research at Staten Island and a member of the Department of Molecular Biology headed by David Miller. Director of the Institute was the late Henry Wisniewski, a distinguished neuropathologist and expert on Alzheimer disease (AD) whose research group was working on the pathological consequences and molecular nature of insoluble aggregates found in AD including neurofibrillary tangles (NFTs) and amyloid plaques. At the time, the primary structure of amyloid- $\beta$ was not known, but in 1984 using guanidine hydrochloride, George Glenner was able to solubilize amyloid isolated from leptomeningeal vessels of Down syndrome and AD patients. Using HPLC, he determined that a main component in his solution was a small peptide of an apparent molecular mass of $4.2 \mathrm{kDa}$. He called this peptide " $\beta$-protein" because of its ability to form noncovalent polymers of $\beta$-pleated sheet structures that aggregated to form fibers identified histologically by Congo red staining and optical polarization properties. He published this data including the sequence of the first 24 residues of $\beta$-protein in two BBRC reports [1, $2]$. At the time, I was working mostly on the genetics of prokaryotes and of scrapie prion (PrP) proteins [3,4], but being at the Institute of Basic Research, I developed an interest in $\mathrm{AD}$. The technology of gene cloning at that time was rather primitive compared to today's standards and was mostly based on reverse genetics using oligonucleotide probes to mimic nucleotide sequence encoding amino acid residues and/or antibodies against specific antigens. Publication of the $\beta$-protein (hereafter referred to as amyloid- $\beta$ ) sequence stimulated my interest to clone the encoding gene, and with the encouragement of both Henry and David, my group, consisting of myself, Ram Ramakrishna and Gloria Wolfe, went to work on the problem.

We prepared oligonucleotide probes based on Glenner's amino acid sequence and started by screening genomic libraries because the origin of amyloid- $\beta$ was unknown, and it was not clear whether or not the protein was expressed in the brain. Actually, at the time, the predominant concept was Glenner's suggestion that amyloid- $\beta$ was an abnormal derivative of a serum precursor protein that was endocytosed and processed in the lysosomal compartment of cerebrovascular endothelial cells. It was thought that following processing, amyloid- $\beta$ was aggregated to form amyloid fibrils that were then exocytosed and deposited in the neuropil or in cerebral vessels (for a detailed account of this concept, see [5]). After a while, it became clear that screening genomic clones was not a very productive route of investigation, as we encountered difficulties stemming 
from the complexity of the human genome and from the presence of other related genomic sequences (see below). This prompted us to screen brain cDNA libraries hoping that, despite Glenner's suggestions that amyloid- $\beta$ was a serum protein, this mysterious gene would also be expressed in the brain. Indeed, this route of investigation quickly proved productive and by early summer of 1986, we had our first cDNA clones. We chose three overlapping clones, we called them B1.1, B2.1 and B2.3, to work with and by late summer we obtained the first nucleotide sequence of clone B2.3 and discovered that it encoded a 97 amino acid sequence including all known amino acids of amyloid- $\beta$ minus the first two $\mathrm{N}$-terminal residues Asp and Ala. Later it became clear that this sequence was the $97 \mathrm{C}$ terminal amino acids of the amyloid- $\beta$ protein precursor $(\mathrm{A} \beta \mathrm{PP})$. Clone $\mathrm{B} 1.1$ was a shorter version of $\mathrm{B} 2.3$ but cDNA B2.1 was much longer, and we hoped then that it may contain the entire sequence of the precursor of amyloid- $\beta$ (for details see [6]). Using cDNA B2.3 as a probe in collaboration with the cytogenetics facility in our Institute, we localized the genomic sequence on chromosome 21 and a letter was later published in Lancet with this information [7].

Our data, including the cDNA sequence encoding amyloid- $\beta$ and the chromosomal localization of its gene, were first presented at a meeting that took place in the Banbury Center at Cold Spring Harbor in November 1986 organized by Peter Davies and Caleb Finch. At the meeting, we also presented data on our genomic clones showing that, although they contained sequence homologous to the gene encoding amyloid- $\beta$, they did not encode it. The meeting was attended by a large number of distinguished scientists, and there I also met for the first time Dr. Goldgaber who presented his data on the cloning of the amyloid- $\beta$ gene. A superbly edited volume containing the proceedings of the meeting was published in the middle of 1987 in: Molecular Neuropathology of Aging, (1987) Banbury Report vol. 27. Cold Spring Harbor Laboratory (P. Davies and C Finch, eds).

I therefore was greatly disappointed to read Dr. Goldgaber's distorted account of my cloning of the amyloid- $\beta$ gene as he describes it in his recent essay "My story: The discovery and mapping to chromosome 21 of the Alzheimer Amyloid gene" [8]. Although I am not in a position to verify the power of his memory concerning other past events, I did notice that his memory is failing him badly when it comes to my presentation at the Banbury conference. As it happens, an excellent record of all the presentations, including transcripts of the discussions that followed each presentation, is contained in the Banbury Report cited above. My chapter in the volume as well as the recorded discussion that followed my presentation clearly show that at the meeting we presented not only the fact that we had obtained cDNA clones encoding amyloid- $\beta$, but also data showing that the encoding gene was on chromosome 21 [6].

It is thus a self-serving distortion of the facts that Dr Goldgaber writes “... Nick had also tried to clone the gene. At the time of Banbury meeting ... he presented ... genomic clones. However, none of his clones contained the correct sequence of Abeta." [8]. He apparently did not wish to acknowledge our cDNA clones! His assertion that at the meeting I told him "... we had no information about the mapping of the gene" is also false. I never told him that. That would have been impossible since I presented data in the same meeting on the mapping of the gene on chromosome 21 , and this in front of a large number of experts! It is really unfortunate that Dr. Goldgaber failed to refresh his memory by consulting the Banbury Report while writing his recollections. Had he done so, he would have realized that during the discussion following my presentation (I presented just before he did), he himself asked me how I had mapped the A $\beta$ PP gene exclusively on chromosome 21 (see page 281 of [6]). I explained that for the in situ chromosomal hybridization, we used our cDNA clone B2.3 as a probe (see also my answer to Dr. Roses questions below).

The Q\&A session that followed my presentation recorded in the Banbury Report also reveals that in contrast to Dr. Goldgaber's assertions, we presented cDNA clones of $\beta$-protein and we reported that the gene was on chromosome 21 at the meeting. Here are three questions and answers copied from the above volume:

Davies (Peter): "I am slightly confused by what you said about the amino acid sequence. You have 97 amino acids encoded by the protein on the cDNA and you are missing just the two first amino acids?"

Robakis: "Yes. The cDNA insert in clone B2.3 that we sequenced encodes 97 amino acids and stops at the EcoRI site defined by the codons of the amino acids glutamate and phenylalanine. ${ }^{1}$ Clone B2.1 should contain the codons for the first two amino

\footnotetext{
${ }^{1}$ This was an EcoRI library.
} 
acids of the amyloid peptide and most or all, of the remaining open reading frame." [page 279 of [6]]. ${ }^{2}$ Roses (Alan): "What was the probe that you used for the in situ hybridization?" Robakis: "That is the amyloid cDNA probe." [page 281 of [6]].

Roses: "Are you saying that the entire multigene family that you are referring to ... are all located on chromosome 21?" Robakis: "No, I'm saying that the genomic sequences that code for the $c D N A$ clone (B2.3) encoding the amyloid peptide-those specific sequences-sit on chromosome 21.” Roses: "And nowhere else?" Robakis: "Nowhere else. There may be related genes on other chromosomes, but we don't know whether they are active genes." [page 279 of [6]].

As the reader appreciates from these conversations, our data in 1986 suggested that there is an A $\beta$ PP multigene family (we discuss this possibility in our chapter of the Banbury Report [6] which readers interested in the topic can consult). Ours was the first suggestion for the existence of such a family. This proved later to be the case by the cloning of other members of the $\mathrm{A} \beta \mathrm{PP}$ family. Our Lancet Letter published in February 14 of 1986 [7] was the first official publication for the cloning and chromosomal localization of the $\mathrm{A} \beta \mathrm{PP}$ gene. Finally, comparison of ours and Dr. Goldgaber's [9] chapters and discussions recorded in the Banbury volume, shows that at the time of the meeting the GoldgaberGadjusek team had only a partial cDNA clone similar to our shortest clone B1.1. The Goldgaber-Gadjusek group had no data on genomic clones. Our team was clearly ahead of theirs with more data at hand on both the cDNA and the genomic clones of $\mathrm{A} \beta \mathrm{PP}$.

Sadly, in his eagerness to re-write scientific history, Dr. Golagaber distorts the facts. It would be unfortunate if this were a deliberate attempt to diminish the contribution of others.

\section{References}

[1] G.G. Glenner and C.W. Wong, Alzheimer's disease: Initial report of the purification and characterization of a novel cerebrovascular amyloid protein, Biochem Biophys Res Commun 120 (1984), 885-890.

[2] G.G. Glenner and C.W. Wong, Alzheimer's disease and Down's syndrome: Sharing of a unique cerebrovascular amyloid fibril protein, Biochem Biophys Res Commun 122 (1984), 1131-1135.

[3] N.K. Robakis, P.R. Sawh, G.C. Wolfe, R. Rubenstein, R.I. Carp and M.A. Innis, Isolation of a cDNA clone encoding the leader peptide of PrP protein and expression of the homologous gene in various tissues, Proc Natl Acad Sci USA 83 (1986), 6377-6381

[4] N.K. Robakis, E.A. Devine-Gage, E.C. Jenkins, R.J. Kascsak, W.T. Brown, M.S. Krawczun and W.P. Silverman, Localization of a Human Gene Homologous to the PrP Gene on the $p$ Arm of Chromosome 20 and Detection of PrP-Related Antigens in Normal Human Brain, Biochem Biophys Res Comm 140 (1986), 758-765.

[5] G.G. Glenner and C.W. Wong, Amyloidosis in Alzheimer's Disease and Down's Syndrome, in: Molecular Neuropathology of Aging, Banbury Report, vol. 27, P. Davies and C. Finch, eds, Cold Spring Harbor Laboratory Press, 1987, pp. 253-265.

[6] N.K. Robakis, G. Wolfe, N. Ramakrishna and H.M. Wisniewski, Isolation of a cDNA clone encoding the Alzheimer's disease and Down syndrome amyloid peptide, in: Molecular Neuropathology of Aging, Bunbury Report, vol. 27, P. Davies and C. Finch, eds, Cold Spring Harbor Laboratory Press, 1987, pp. 267-281.

[7] N.K. Robakis, H.M. Wisniewski, E.C. Jenkins, E.A. DevineGage, G.E. Houch, X.-L. Yao, N. Ramakrishna, G. Wolfe, W.P. Silverman and W.T. Brown, Chromosome 21q21 sublocalization of the gene encoding the $\beta$-amyloid peptide present in cerebral vessels and neuritic (senile) plaques of people with Alzheimer disease and Down syndrome, Lancet 1 (1987), 384-385.

[8] D. Goldgaber, My story: the discovery and mapping to chromosome 21 of the Alzheimer amyloid gene, in: Alzheimer's Disease: A Century of Scientific and Clinical Research, G. Perry, J. Avila, J. Kinoshita and M.A. Smith, eds, IOS Press, Amsterdam, 2006, pp. 349-360.

[9] D. Goldgaber, M.I. Lerman, W.O. McBride, U. Saffioti and C.D. Gajdusek, Isolation, Characterization, and Chromosomal Localization of a Human Brain cDNA Clone Coding for the Amyloid $\beta$-Protein Found in Alzheimer's Disease, Down's Syndrome, and Aging Brain, in: Molecular Neuropathology of Aging, Bunbury Report, vol. 27, P. Davies and C. Finch, eds, Cold Spring Harbor Laboratory Press, 1987, pp. 283-293.

[10] N.K. Robakis, N. Ramakrishna, G. Wolfe and H.M. Wisniewski, Molecular cloning of cDNA encoding the cerebrovascular and neuritic plaque amyloid peptides, Proc Natl Acad Sci USA 84 (1987), 4190-4194.

\footnotetext{
${ }^{2}$ cDNA clone B2.1 did indeed contain the two missing N-terminal amino acids of the amyloid peptide as well as most of $\mathrm{A} \beta \mathrm{PP}$ amino acids upstream of the amyloid- $\beta$ sequence. It is this clone that we reported in our PNAS paper [10].
} 